\title{
NATURAL HISTORY NOTE \\ Northern record for Tadarida teniotis (NE Ukraine) far from known species range
}

\author{
Alona Prylutska ${ }^{1,2}$, Marharyta Moiseienko ${ }^{1}$, Maryna Yerofieieva ${ }^{1,3}$, Vitalii Hukov ${ }^{1,2,3}$, Anton Vlaschenko ${ }^{1,2,4,{ }^{*}}$
}

\author{
1. Bat Rehabilitation Center of Feldman \\ Ecopark, 62340 Lesnoye, Kharkiv Region, \\ Ukraine. \\ 2. Ukrainian Independent Ecology \\ Institute, Plekhanov st., 4061001 \\ Kharkiv, Ukraine. \\ 3- Biological department, V.N. Karazin \\ Kharkiv National University, Svobody sq. \\ 4, 61077 Kharkiv, Ukraine. \\ 4- National Scientific Center "Institute \\ of Experimental and Clinical Veterinary \\ Medicine", Kharkiv, 61023, Ukraine. \\ *Corresponding author: \\ anton.vlaschenko@gmail.com
}

\begin{abstract}
An unexpected record of Tadarida teniotis (Rafinesque, 1814) (adult male) was made in Kharkiv city, NE Ukraine. The bat was found in a private flat on the thirteenth floor of a multi-storey building (1970s construction). This new record is much further North than documented from in-hand and acoustic records of this species in the Russian Caucasus - 850 km, Bulgaria - 1200 km, and Crimea - 600 km. Two main interpretations of this record are presented: (i) it represents a species range expansion due to urbanization and climate warming, or (ii) an accidental transportation by a vehicle. In either of these circumstances, this species should to be included in the bat species list of the Ukraine.
\end{abstract}

DOI: https://doi.org/10.14709/BarbJ.13.1.2020.17

Keywords: bats, European free-tailed bat, Tadarida teniotis, introduced species, urbanization, range expansion, Ukraine

\section{INTRODUCTION}

Global climate warming, urbanization, and natural habitat degradation are three main factors affecting biodiversity in a predominantly negative way. However, some volant vertebrates of temperate latitudes (insectivorous birds and bats) that depend on seasonal resources could benefit from increased survival and reproductive success under global warming scenarios (e.g. Radchuk et al. 2019). Among volant vertebrates, bats are much less studied than birds, however, even for them there are still examples of species range expansions which are likely due to climate warming but also in response to urbanization (e.g. Ilyin 2000, Lundy et al. 2010, Godlevska 2015, Sachanowicz et al. 2019). Both of these factors are equally important for driving range expansions of some bat species in the Northern Hemisphere.

The European free-tailed bat, Tadarida teniotis (Rafinesque, 1814) has been recorded frequently on the northern margin of its range in the last 20 years (Benda \& Horáček 1998, Ciechanowski et al. 2005, Gazaryan \& Tembotova 2007, Uhrin et al. 2009, Zagmajster et al. 2015, Milanolo et al. 2017, Pejić et al. 2017, Dundarova et al. 2019, Presetnik \& Šalamun 2019). Tadarida teniotis is the only species of the predominantly tropical bat family Molossidae to be found in Europe (Benda \& Piraccini 2016, Dietz \& Kiefer 2016, Amorim et al. 2020). The European range of this species in the western part covers the Iberian Peninsula, the northern Mediterranean up to Switzerland, Northern Italy, and southern Balkans (Benda \& Piraccini 2016, Dietz \& Kiefer 2016). Further in the east, the species is recorded in Crimea
(Uhrin et al. 2009) and in Russian Caucasus (Gazaryan \& Tembotova 2007), and those locations were considered the northern margin of the species range in the east (Benda \& Piraccini 2016). The ecomorphological features of this species (fast-flying and aerial hawking of insects at higher altitudes) make it hard to capture using mist-nets. However, the use of species-specific echolocation calls means this species is easily identifiable using ultrasound detectors. Indeed, most of the new records of $T$. teniotis have been made using acoustic identification (Benda \& Horáček 1998, Ciechanowski et al. 2005, Uhrin et al. 2009, Zagmajster et al. 2015, Milanolo et al. 2017, Pejić et al. 2017, Presetnik \& Šalamun 2019), and only a few include sightings of individuals (Gazaryan \& Tembotova 2007, Dundarova et al. 2019).

Tadarida teniotis is a common urban bat species in Spain and Italy that roosts in different kinds of human constructions (Balmori 2007, 2018, Monsalve-Dolz 2014, Russo \& Ancillotto 2015). Increasing urbanization over the last 70 years has allowed urban and rural tolerant bat species to expand their ranges (e.g. Sachanowicz et al. 2006, Russo \& Ancillotto 2015, Hukov et al. 2020). Do these new records for $T$. teniotis over the last 20 years show species range expansion to the north, or it is just a result of using more advanced acoustic techniques in bat surveys? A similar case may be see in America where the Molossidae Tadarida brasiliensis, a successful urban explorer (e.g. Li \& Wilkins 2015) that occupies USA cities, is also showing further range expansion (e.g. McCracken et al. 2018). 
Here we present the new record of $T$. teniotis in the northeastern Ukrainian city - Kharkiv, hundreds of kilometres further north from the present species range, and discuss two main hypotheses of the origin of the specimen.

\section{MATERIALS AND METHODS}

The Bat Rehabilitation Centre of Feldman Ecopark (BRC-FE) provides a call-centre which collects information about factual and correspondence records of bats mainly in Kharkiv city, but also throughout the Ukraine (Vlaschenko \& Prylutska 2018) and from other countries; BRC-FE staff also provide a rescue service, visiting people who find bats in Kharkiv city.

Bats arriving at the BRC-FE office have their sex, age category, reproductive status, forearm length (accuracy $0.1 \mathrm{~mm}$ ), and body mass (accuracy $0.1 \mathrm{~g}$ ) recorded and are subsequently banded according to the protocol described by Vlaschenko et al. 2020. For details of the methods used for age category classification see Kravchenko et al. 2017. Injured individuals are examined by a veterinarian and receive appropriate treatment. Bats which are not capable of flying when they arrive stay at BRC-FE for long-term rehabilitation, all the others are released in the next evening as long as climatic conditions are appropriate.

The BRC-FE works under the general permission of the Kharkiv Oblast Authority of Ecology and Natural Resources.

\section{RESULTS}

A record of an adult male $T$. teniotis was obtained 16th June 2020 in Kharkiv city $\left(49,9935^{\circ} \mathrm{N}, 36,2304^{\circ} \mathrm{E}\right), \mathrm{NE}$ Ukraine. The bat was found in a private flat on the thirteenth floor (nearly 40 metres high) of a forty-year-old multi-storey building (Fig. 1), $2 \mathrm{~km}$ from the northern administrative city border, and $6.5 \mathrm{~km}$ from the city center. The forearm length of the bat was $61,7 \mathrm{~mm}$ and body mass was $24,3 \mathrm{~g}$. The bat had two symmetric wounds on the upper edge of both ears (Fig. 2). There were necrosis zones $2 \times 3(4) \mathrm{mm}$ the same size on both ears, possibly affected by extreme high temperatures. Wing punch samples were collected and preserved in ethanol for future genetic studies.

\section{DISCUSSION}

Here we describe the record of $T$. teniotis, Kharkiv city Ukraine, the first in-hand record of a specimen for over a hundred years (last record for Crimea described in 19th century, for details see Uhrin et al. 2009). Further, we discuss this record from the contrasting points of view of two main hypotheses: (i) a case of extraordinary range expansion to the north of this bat species' normal distribution, or (ii) a case of passive transportation of an individual by a vehicle.

The nearest records of $T$. teniotis to Kharkiv city were previously made in Crimea - $600 \mathrm{~km}$ (Uhrin et al. 2009), in the Russian Caucasus - 850 km (Gazaryan \& Tembotova 2007) and in Bulgaria - 1200 km (Dundarova et al. 2019).

Bats of Ukrainian cities are well studied by bat rehabilitation centres and call-centres in different parts of the

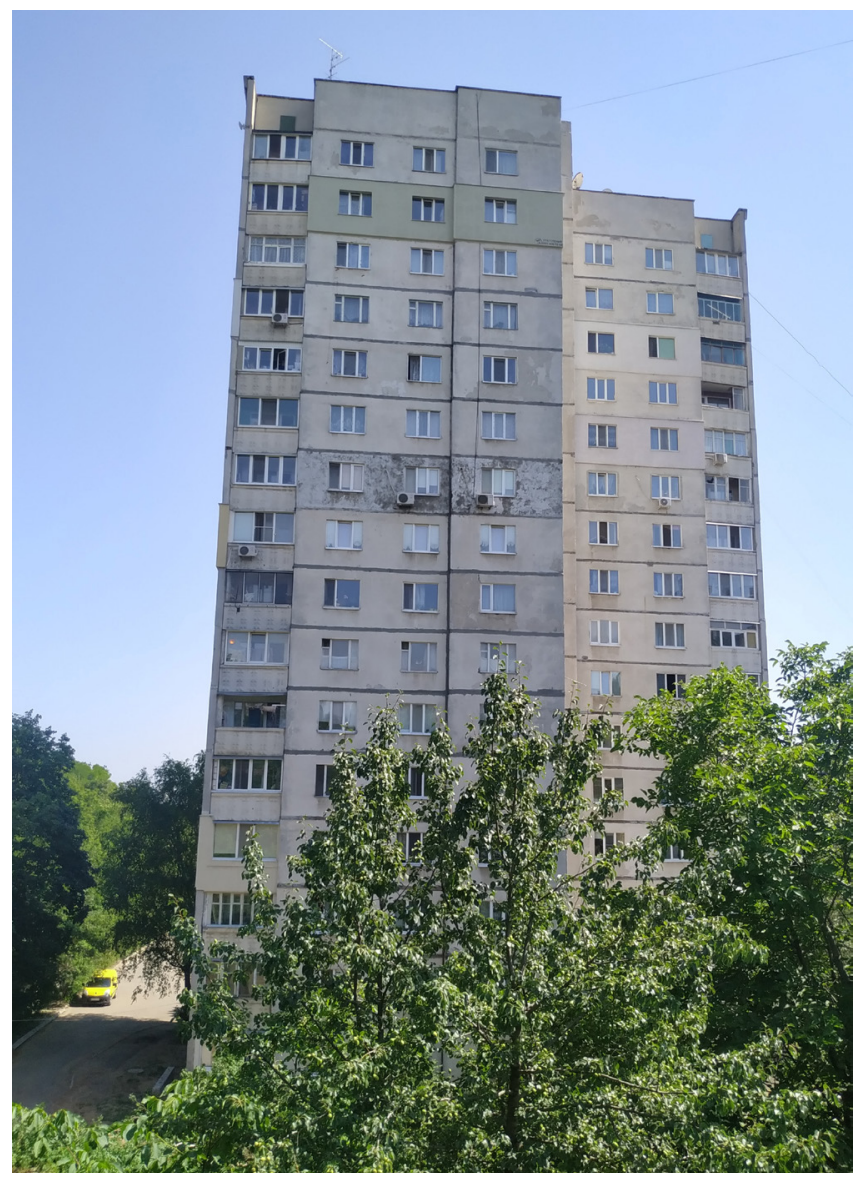

Fig. 1 - The building where T. teniotis was found in Kharkiv city, Ukraine.

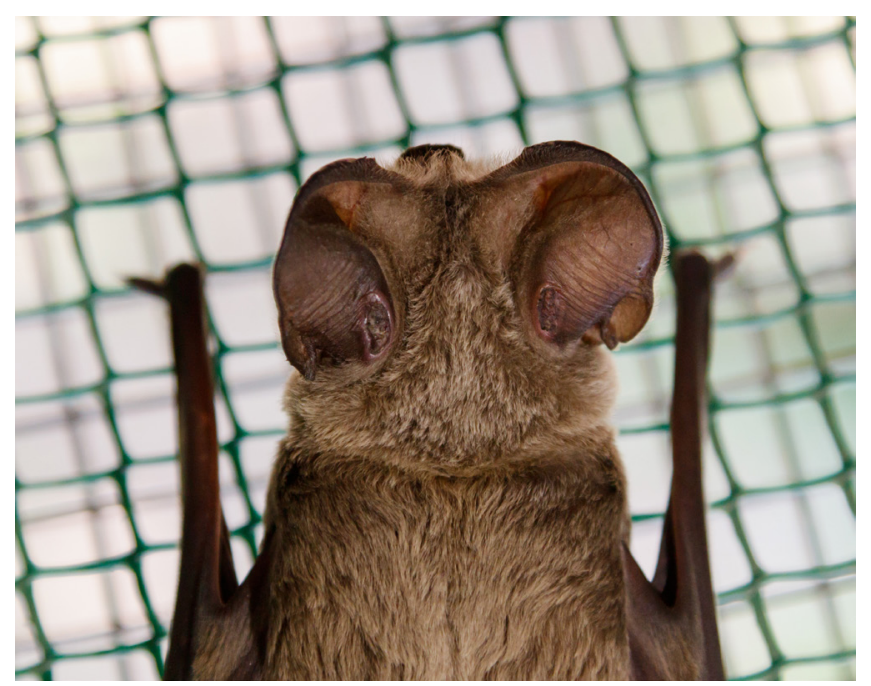

Fig. 2 - Wounds on the upper edge of T. teniotis' ears (picture was taken ten days after the bat was found).

country. Substantial records of bats have been documented for the last 10-15 years (e.g. Godlevska 2012, Prylutska \& Vlaschenko 2013, Kravchenko et al. 2017, Panchenko \& Godlevska 2018, Hukov et al. 2020) especially in the south, central and eastern parts of the country. The emergence of "new" bat species in additional areas or changes in a species phenology status are also well documented; see cases of Plecotus austriacus and Pipistrellus nathusii (e.g. Godlevska 2012, Prylutska \& Vlaschenko 2013, Zagorodniuk 2019). It was the routine activities of the BRC-FE that were also responsible for recording this individual of $T$. teniotis. The most recent acoustic record of $T$. teniotis for all of the 
Ukraine was made in 2009 in Crimea (Uhrin et al. 2009) which restarted the discussion about the presence of this species in Ukraine. However, there were no new records of the species for the next 10 years. It is unlikely that this species already occupied some part of continental Ukraine and was not detected or found by local conservationists. However, the level of acoustic studies in Ukraine is far behind other countries in the European Union, and urban landscapes may be providing increasingly suitable habitats for this species.

The more reasonable explanation for this $T$. teniotis record in Kharkiv is passive transportation of this individual by a vehicle. There are many examples of accidental longdistance movement of bats by human transport, between countries (e.g. Smirnov \& Vehnik 2011) but also between continents and overseas (e.g. Constantine 2003, Hutterer et al. 2005, Ahlén et al. 2009, Petersen et al. 2014, Rydell et al. 2014, Lohi 2015, Hüppop \& Hill 2016). The low body mass of an individual from Kharkiv (compared to normal range, Dietz \& Kiefer 2016), and wounds on the bat's ears, might support the hypothesis of passive transportation. The wounds could have resulted from burns if the bat was sitting under a working engine. This version could explain the symmetric position of the wounds on the upper edges of its ears. However, the date of the record was at the end of COVID-19 quarantine lockdown with few international movements and international airport in Kharkiv closure. As an additional explanation of this T. teniotis record in Kharkiv city, we suggest disorientation of the individual in high altitudes and its passive transportation by air currents.

Finally, under any of the circumstances, this species should to be included in the bat species list of Ukraine, as an in-hand record verifies previous acoustic records of $T$. teniotis in Crimea in 2009. However, in our opinion T. teniotis cannot be included in the bat species list of the Kharkiv region based on this single record.

\section{ACKNOWLEDGMENTS}

The authors would like to thank the following people from the Bat Rehabilitation Center of Feldman Ecopark's team: Kseniia Kravchenko, Tatiana Yurieva, Olena Rodenko, Anastasia Domanska, and all the others who support the center. We are very grateful to Lisa Worledge, Bat Conservation Trust (UK) for correction of the English language. The Bat Rehabilitation Center of Feldman Ecopark is funded mostly by the International Charity Foundation "Oleksandr Feldman Foundation".

\section{REFERENCES}

AHLÉN, I., BAAG $\varnothing E$, H. J. \& BACH, L. (2009). Behavior of Scandinavian Bats during Migration and Foraging at Sea. J Mammal, 90(6): 1318-1323. https://doi. org/10.1644/09-MAMM-S-223R.1

AMORIM, F., RAZGOUR, O., MATA, V. A., LOPES, S., GODINHO, R., IBÁNEZ, C., JUSTE, J., ROSSITER, S. J., BEJA, P. \& REBELO, H. (2020). Evolutionary history of the European free-tailed bat, a tropical affinity species spanning across the Mediterranean Basin. J Zool Syst Evol Res, 58(1): 499518. https://doi.org/10.1111/jzs.12326
BALMORI, A. (2007). Tadarida teniotis (Rafinesque, 1814). In: Atlas y Libro Rojo de los Mamíferos Terrestres de España. ed.: Dirección General para la BiodiversidadSECEM-SECEMU. Madrid, España, p.267-271.

BALMORI, A. (2018). Advances on the group composition, mating system, roosting and flight behaviour of the European free-tailed bat (Tadarida teniotis). Mammalia, 82(5): 460-468. https://doi. org/10.1515/mammalia-2017-0083

BENDA, P. \& HORÁČEK, I. (1998). Bats (Mammalia: Chiroptera) of the Eastern Mediterranean. Part 1: Review of distribution and taxonomy of bats in Turkey. Acta Societas Zoologicae Bohemicae, 62: 255-313.

BENDA, P. \& PIRACCINI, R. (2016). Tadarida teniotis. The IUCN Red List of Threatened Species 2016: e.T21311A22114995. https://doi.org/10.2305/IUCN. UK.2016-2.RLTS.T21311A22114995.en

CIECHANOWSKI, M., SACHANOWICZ, K., RACHWALD, A. \& BENDA, P. (2005). First records of Tadarida teniotis (Rafinesque, 1814) (Chiroptera, Molossidae) from Serbia and Montenegro and from Bosnia and Herzegovina. Mammalia, 69(2): 257-260. https://doi. org/10.1515/mamm.2005.024

CONSTANTINE, D. G. (2003). Geographic Translocation of Bats: Known and Potential Problems. Emerg Infect Dis, 9(1): 17-21.https://doi.org/10.3201/eid0901.020104

DIETZ, C. \& KIEFER, A. (2016). Bats of Britain and Europe. ed.: Bloomsbury. London, United Kingdom, 398pp.

DUNDAROVA, H., GORANOV, S. \& RACYOV, D. (2019). The northernmost point of distribution of the European free-tailed bat Tadarida teniotis (Rafinesque, 1814) (Mammalia: Chiroptera) in Bulgaria. ZooNotes, 7: 167170.

GAZARYAN, S. \& TEMBOTOVA, F. A. (2007). New significant findings of bats (Chiroptera) in the Central Caucasus. Zoologicheskiy Zhurnal, 86(6): 761-762.

GODLEVSKA, L. V. (2012). Results of the work of the bat contact-centre (Ukraine). Scientific Notes of Taurida VI Vernadsky National University. Series: Biology, Chemistry, 25(64): 12-20.

GODLEVSKA, O. (2015). Results of the work of the Kyiv bat contact-centre in 2012-2015. Proceedings of the Theriological School, 13: 11-19. https://doi. org/10.15407/ptt2015.13.011

HUKOV, V., TIMOFIEIEVA, O., PRYLUTSKA, A., RODENKO, O., MOISEIENKO, M., BOHODIST, V., DOMANSKA, A. \& VLASCHENKO, A. (2020). Wintering of an urban bat (Pipistrellus kuhlii lepidus) in recently occupied areas. European Journal of Ecology, 6(1): 102-120. https://doi.org/10.17161/eurojecol.v6i1.13629 
HUTTERER, R., IVANOVA, T., MEYER-CORDS, C. H. \& RODRIGUES, L. (2005). Bat migration in Europe. A review of banding data and literature. ed.: Federal Agency for Nature Conservation. Bonn, Germany, 180pp.

HÜPPOP, O. \& HILL, R. (2016). Migration phenology and behaviour of bats at a research platform in the southeastern North Sea. Lutra, 59(1-2): 5-22.

ILYIN V. Y. (2000). Dynamics of the ranges of three bat species in the extreme south-east of Europe. Plecotus et al., 3: 43-49.

KRAVCHENKO, K., VLASCHENKO, A., PRYLUTSKA, A., RODENKO, O., HUKOV, V. \& SHUVAEV, V. (2017). Yearround monitoring of bat records in an urban area: Kharkiv (NE Ukraine), 2013, as a case study. Turk J Zool, 41: 530-548. https://doi.org/10.3906/zoo-1602-51

LI, H. \& WILKINS, K. T. (2015). Selection of Building Roosts by Mexican Free-Tailed Bats (Tadarida brasiliensis) in an Urban Area. Acta Chiropterol, 17(2): 321-330. https:// doi.org/10.3161/15081109ACC2015.17.2.007

LOHI, S. E. H. (2015). Hitchhiking Bats on the Great Lakes of North America. Michigan Technological University. Houghton, Michigan, United State Of America. Michigan Technological University.

LUNDY, M., MONTGOMERY, I. \& RUSS, J. (2010). Climate change-linked range expansion of Nathusius' pipistrelle bat, Pipistrellus nathusii (Keyserling \& Blasius, 1839). J Biogeogr, 37(12): 2232-2242. https://doi.org/10.1111/ j.1365-2699.2010.02384.x

MCCRACKEN, G. F., BERNARD, R. F., GAMBA-RIOS, M., WOLFE, R., KRAUEL, J. J., JONES, D. N., RUSSELL, A. L. \& BROWN, V. A. (2018). Rapid range expansion of the Brazilian free-tailed bat in the southeastern United States, 2008-2016. J Mammal, 99(2): 312-320. https:// doi.org/10.1093/jmammal/gyx188

MILANOLO, S., PAŠIĆ, J., KARAPANDŽA, B., MULAOMEROVIĆ, J. \& PRESETNIK, P. (2017). Further records of European free-tailed bat (Tadarida teniotis) in Bosnia and Herzegovina and associated observations. Hypsugo, 2(1): 42-45.

MONSALVE-DOLZ, M. A. (2014). Eventos de mortalidad accidental de Murciélago rabudo Tadarida teniotis en edificios altos de la ciudad de Valencia (España). Journal of Bat Research \& Conservation, 7(1): 35-38. https://doi. org/10.14709/BarbJ.7.1.2014.07

PANCHENKO, P. \& GODLEVSKA, L. (2018). Data on the bat fauna of the Northern Black Sea Region based on results of the work of bat contact centres. Theriologia Ukrainica, 16: 120-126. https://doi.org/10.15407/pts2018.16.120

PEJIĆ, B., BUDINSKI, I., KARAPANDŽA, B. \& PAUNOVIĆ, M. (2017). The first record of European free-tailed bat Tadarida teniotis (Rafinesque, 1814) in Serbia. Bulletin of the Natural History Museum, 10: 105-111. https://doi. org/10.5937/bnhmb1710105P
PETERSEN, A., JENSEN, J-K., JENKINS, P., BLOCH, D. \& INGIMARSSON, F. (2014). A Review of the Occurrence of Bats (Chiroptera) on Islands in the North East Atlantic and on North Sea Installations. Acta Chiropterol, 16(1): 169-195. https://doi.org/10.3161/150811014X683381

PRESETNIK, P. \& ŠALAMUN, A. (2019). First records of the European free-tailed bat Tadarida teniotis (Rafinesque, 1814 ) in Slovenia. Natura Sloveniae, 21(1):47-53.

PRYLUTSKA, A. S. \& VLASCHENKO, A. S. (2013). Material on bat distribution on the base of results of contact-center in Kharkov (2008-2012). Biological Systems, 5(4): 532537.

RADCHUK, V., REED, T., TEPLITSKY, C., VAN DE POL, M., CHARMANTIER, A., HASSALL, C., ADAMÍK, P., ADRIAENSEN, F., AHOLA, M. P., ARCESE, P., et al. (2019). Adaptive responses of animals to climate change are most likely insufficient. Nat Commun, 10: 3109. https:// doi.org/10.1038/s41467-019-10924-4

RUSSO, D. \& ANCILLOTTO, L. (2015). Sensitivity of bats to urbanization: a review. Mamm Biol, 80(3): 205-212. https://doi.org/10.1016/j.mambio.2014.10.003

RYDELL, J., BACH, L., BACH, P., DIAZ, L. G., FURMANKIEWICZ, J., HAGNER-WAHLSTEN, N., KYHERÖINEN, E-M., LILLEY, T., MASING, M., MEYER, M. M., et al. (2014). Phenology of Migratory Bat Activity Across the Baltic Sea and the South-Eastern North Sea. Acta Chiropterol, 16(1): 139147. https://doi.org/10.3161/150811014X683354

SACHANOWICZ, K., WOWER, A. \& BASHTA, A-T. (2006). Further range extension of Pipistrellus kuhlii (Kuhl, 1817) in central and eastern Europe. Acta Chiropterol, 8(2): $\quad$ 543-548. https://doi.org/10.3161/17335329(2006)8[543:FREOPK]2.0.CO;2

SACHANOWICZ, K., CIECHANOWSKI, M., TRYJANOWSKI, P. \& KOSICKI, J. Z. (2019). Wintering range of Pipistrellus nathusii (Chiroptera) in Central Europe: has the species extended to the north-east using urban heat islands?. Mammalia, 83(3): 260-271. https://doi. org/10.1515/mammalia-2018-0014

SMIRNOV, D. G. \& VEHNIK V. P. (2011). On the modern distribution of Pipistrellus kuhlii (Chiroptera: Vespertilionidae) in the Volga region. Povolzhskiy Journal of Ecology, 2: 193-202.

UHRIN, M., GAZARYAN, S. \& BENDA, P. (2009). Does Tadarida teniotis really occur in Crimea? (Chiroptera: Molossidae). Lynx, n. s. (Praha), 40: 115-126.

VLASCHENKO, A. S. \& PRYLUTSKA, A. S. (2018). The Bat Rehabilitation Center of the "Feldman Ecopark", Kharkiv, Ukraine. Nyctalus (N.F.), 19(2): 158-161. https://doi. org/10.13140/RG.2.2.12508.03205

VLASCHENKO, A., PRYLUTSKA, A., KRAVCHENKO, K., RODENKO, O., HUKOV, V., TIMOFIEIEVA, O., HOLOVCHENKO, O., MOISEIENKO, M. \& KOVALOV, V. (2020). Regional recaptures of bats (Chiroptera, Vespertilionidae) ringed in Eastern Ukraine. Zoodiversity, 54(1): 53-66. https:// doi.org/10.15407/zoo2020.01.053 
ZAGMAJSTER, M., DORIGO, L. \& LAPINI, L. (2015). First records of European free-tailed bat Tadarida teniotis Rafinesque, 1818 (Chiroptera: Molossidae) in Friuli Venezia Giulia region in NE Italy. Natura Sloveniae, 17(2):77-84.

ZAGORODNIUK, I. (2019). Range dynamics in sibling species: facts and reconstructions for the mammal fauna of Eastern Europe. Theriologia Ukrainica, 18: 20-39. https:// doi.org/10.15407/pts2019.18.020 